\title{
Laboratory Diagnosis of Late-Onset Male Hypogonadism Andropause
}

\section{original article}

\author{
Ruth Clapauch \\ Aline Machado Carmo \\ LIZANKA MARINHEIRO \\ SALO BUKSMAN \\ IsABEL PESSOA
}

Hospital da Lagoa (RC, AMC); Instituto Fernandes Figueira, Fiocruz (LM); Instituto Nacional de Traumato Ortopedia (INTO), Ministério da Saúde (SB);

Diagnósticos da América (IP); Rio de Janeiro, RJ, Brasil.

Received in 29/6/2008 Acepted in 9/9/2008

\section{ABSTRACT}

Objectives: To evaluate which factors influence the laboratorial diagnosis of late-onset male hypogonadism (LOH). Methods: Total testosterone (TT), SHBG and albumin were measured in 216 men aged $52-84$ years. The laboratorial definition of LOH was two values of calculated free testosterone (cFT) $<6.5 \mathrm{ng} / \mathrm{dl}$, according to Vermeulen's formula. Results: At the first blood test, cFT was $<6.5 \mathrm{ng} / \mathrm{dl}$ in $27 \%$ of the men. Laboratorial LOH (confirmed by two tests) was present in $19 \%$, but TT levels were low in only $4.1 \%$. Age influenced TT ( $p=0.0051$ ) as well as BMI; $23.5 \%$ of patients $\geq 70$ years and $38.9 \%$ of the obese men who had TT within the reference range were, in fact, hypogonadal. Conclusion: Especially in obese men and in those $\geq 70$ years old, SHBG dosage is important to calculate FT levels and diagnose hypogonadism. (Arq Bras Endocrinol Metab 2008; 52/9:1430-1438)

Keywords: Andropause; Late-onset male hypogonadism; Diagnosis; Total testosterone; Calculated free testosterone

\section{RESUMO}

\section{Diagnóstico Laboratorial do Hipogonadismo Masculino Tardio (An- dropausa)}

Objetivos: Avaliar os fatores que influenciam o diagnóstico laboratorial do hipogonadismo masculino tardio. Métodos: Avaliamos 216 homens entre 52 e 84 anos. 0 diagnóstico laboratorial foi definido como dois valores de testosterona livre calculada (TLC) $<6,5 \mathrm{ng} / \mathrm{dl}$, segundo a fórmula de Vermeulen, a partir das dosagens de testosterona total (TT), SHBG e albumina. Resultados: Na primeira dosagem, a TLC foi $<6.5 \mathrm{ng} / \mathrm{dl}$ em $27 \%$ da amostra. Hipogonadismo laboratorial (confirmado por duas dosagens) esteve presente em 19\%, no entanto a TT foi baixa em apenas $4.1 \%$ dos homens. A idade influenciou a TT ( $p=0.0051$ ) bem como o IMC; $23,5 \%$ dos homens $\geq 70$ anos e $38,9 \%$ dos obesos com TT dentro dos níveis de referência eram, na verdade, hipogonádicos. Conclusão: Especialmente em homens obesos e nos $\geq 70$ anos a dosagem de SHBG é importante para calcular TL e diagnosticar o hipogonadismo. (Arq Bras Endocrinol Metab 2008; 52/9:1430-1438)

Descritores: Andropausa; Hipogonadismo masculino tardio; Diagnóstico; Testosterona total; Testosterona livre calculada

\section{INTRODUCTION}

t is challenging to establish a diagnosis of late-onset male hypogonadism; the symptoms are non-specific, and most of them can be related to advanced age or other hormonal conditions. Since there are no clinical pathognomonic parameters, the diagnosis of late-onset hypogonadism depends on the presence of clinical symptoms associated with a reduction in the plasma levels of androgens (1). Even so, the biochemical definition of hypotestosteronemia in elderly 
men has not been established yet. A total testosterone (TT) level of $>320 \mathrm{ng} / \mathrm{dl}(11.1 \mathrm{nM})$ is considered nor$\mathrm{mal}$, and TT $<200 \mathrm{ng} / \mathrm{dl}(6.9 \mathrm{nM})$ is diagnostic of hypogonadism, but controversy exists in the TT range between 320 and $200 \mathrm{ng} / \mathrm{dl}(6.9-11.1 \mathrm{nM})$ (2). These laboratory-established ranges are related to all adult men, and they do not take into consideration the interval variation among age groups. Furthermore, there is no indication of the average or median levels for a specific age or ethnic group (2).

Several clinical, analytical and pre-analytical factors should be taken into consideration when appraising the plasma testosterone level. The serum level of testosterone has a circadian variation, with higher levels in the morning and lower levels at night. The variation in the testosterone level can reach $50 \%$ under the peak; therefore, blood for measuring testosterone levels should be collected between eight and ten in the morning (3).

Testosterone circulates through the plasma in three forms: free testosterone (FT, 2-3\% of the total), testosterone bound to sex hormone-binding protein (SHBG) (60-70\%), and testosterone bound to albumin (30$40 \%)$. SHBG strongly and stably binds with testosterone, while the interaction with albumin is significantly weaker (4). Thus, only the free testosterone and that bound to albumin are able to bind to the testosterone receptor, with the sum of these forms considered bioavailable testosterone (BT).

With aging, the SHBG levels rise and as a consequence the total testosterone levels remain stable or slightly elevated, while the free and bioavailable testosterone levels drop sharply. For this reason, the gold standard for the clinical diagnosis of hypogonadism is establishing two values of FT $<6.5 \mathrm{ng} / \mathrm{dl}$ obtained with a minimum interval of one month (3). The FT represents a very small portion of total testosterone, and a precise and accurate method is needed for its adequate measurement. The measurement of free testosterone levels by radioimmunoassay, a widely available method, is not trustworthy. The measurement of FT by equilibrium dialysis is considered reliable; however, it is a complex and cumbersome technique that is available only in research centers and not in clinical laboratories. Thus, FT should be obtained by equilibrium dialysis or by a method with equivalent efficacy such as Vermeulen's formula, which is performed by calculating FT and BT from the measured TT, SHBG and albumin.

Several different conditions can influence the serum levels of testosterone including renal, cardiac, res- piratory and hepatic diseases, inflammatory conditions, and severe diseases. In addition, several drugs are able to reduce the serum levels of testosterone, such as estrogens, GnRH agonists and antagonists, opioids, thiazides, psychotropic agents and amiodarone (3). Many other conditions and drugs can also influence the levels of SHBG and change the levels of total testosterone. The agents and conditions that increase SHBG levels are estrogens, anticonvulsants, hyperthyroidism, hepatic diseases, GH deficiency and HIV infection. The agents that reduce the levels of SHBG are androgens, glucocorticoids, progestins, hypothyroidism, GH excess and nephrotic syndrome (1).

With the challenge represented by the diagnosis of late-onset male hypogonadism (andropause), the present study has as its objective the evaluation of which factors influence hormonal levels required for its diagnosis.

\section{SUBJECTS AND METHODS}

Two hundred and sixteen patients from the Male Osteoporosis Detection Program from the Instituto Nacional de Traumato-Ortopedia (INTO), conducted by the Health Ministry, were evaluated at the Andrology outpatient clinic of Hospital da Lagoa. The INTO program was created to evaluate the prevalence of osteoporosis in men over 50 years old in Rio de Janeiro. About 800 men independently contacted this program up to January 2005 , after announcements on the radio, television and in newspapers offering a free bone mass evaluation for men above 50 years of age. All the men who contacted the program had a lumbar spine and hip bone densitometry performed.

Men diagnosed with osteoporosis (132 of the 800) were later on called by telephone, telegram, and/or letter to come in for a further evaluation of their sexual hormones at the Andrology outpatient clinic of Hospital da Lagoa, as part of the investigation for causes of osteoporosis. One hundred and ten (110) of the 132 men with osteoporosis went to Hospital da Lagoa. For almost every man with osteoporosis who came to the hospital, another patient with a normal densitometry, paired by age and race, was chosen from the list of men who took part in the INTO program, totaling 106 patients with normal bone density. All 216 subjects were then divided in the following age groups: 50-59 years $(\mathrm{n}=30.15$ with osteoporosis and 15 with normal bone density), 60-69 years ( $\mathrm{n}=96.48$ with osteoporosis and 
48 with normal bone density), and 70 or more years $(\mathrm{n}=90.47$ with osteoporosis and 43 with normal bone density). The last group included 14 men with $80-84$ years, 7 with osteoporosis and 7 with normal bone density. Men from the INTO program diagnosed with osteopenia were not contacted.

At the Andrology clinic of Hospital da Lagoa the survey was explained, and written informed consent was obtained, according to the protocol approved by the Ethics Committee. A medical exam, including questionnaires focusing on changes of the sexual steroids, was conducted. A general physical exam was performed, including the genitals but excluding a rectal prostate exam. For the clinical diagnosis of andropause the results of these questionnaires and the spontaneous complaints presented by the patients, as well as the findings of the physical exam, were all considered.

\section{Hormonal dosages}

At the patient's first visit to Hospital da Lagoa, a blood collection was scheduled to be performed at the laboratory of the Instituto Fernandes Figueira between 8:30 and 10:00 in the morning. General laboratory exams were performed, including albumin levels. A portion of the collected blood sample was separated and taken to the Diagnósticos da América Laboratory, where tests for the levels of total testosterone (TT) and SHBG were performed. With these values, the calculated free testosterone $(\mathrm{cFT})$ and calculated bioavailable testosterone (cBT) were obtained through the website www.issam. $\mathrm{ch} /$ freetesto.htm, according to Vermeulen`s formula:

$$
[\mathrm{FT}]=\frac{[\mathrm{T}]-\mathrm{N} *[\mathrm{FT}]}{\mathrm{KSHBG} *\{[\mathrm{SHBG}]-[\mathrm{T}]+\mathrm{N} *[\mathrm{FT}]\}}
$$

Where $\mathrm{N}=\mathrm{l}+\mathrm{KA}^{*}[\mathrm{~A}],[\mathrm{T}]=$ total concentration of serum testosterone $(\mathrm{mol} / \mathrm{l}),[\mathrm{SHBG}]=$ serum concentration of sexual hormone binding globulin $(\mathrm{mol} / \mathrm{l})$, $[\mathrm{A}]=$ serum concentration of albumin $(\mathrm{mol} / \mathrm{l}), \mathrm{KSHBG}$ $=$ affinity constant of testosterone for SHBG $=1 \times 109$ $\mathrm{mol} / \mathrm{l}$, and $\mathrm{KA}=$ affinity constant of testosterone for albumin $=3.6 \times 104 \mathrm{~mol} / 1$.

At the second visit, the patient was informed about the result of the exams. If the values of cFT were $<6.5 \mathrm{ng} /$ $\mathrm{dl}$ or those of cBT were $<140 \mathrm{ng} / \mathrm{dl}$, a second blood collection was scheduled with an interval of at least one month from the first exam. The levels of total testosterone and SHBG were again determined by the Diagnósticos da America Laboratory in order to recalculate the bioavaila- ble and free testosterone. The follicle-stimulating hormone (FSH), lutenizing hormone ( $\mathrm{LH})$ and prolactin levels were determined at the Instituto Fernandes Figueira to exclude secondary causes of hypogonadism.

The total testosterone was measured by chemiluminescence using an automated Advia Centaur kit (Bayer Diagnostics) with an analytical sensitivity of $100 \mathrm{ng} / \mathrm{dl}$ (reference value in men ranges from $24 \mathrm{l}$ to $827 \mathrm{ng} / \mathrm{dl}$ ). SHBG was also determined using a chemiluminescence kit (Immulite 1000; Siemens) with an analytical sensitivity of $0.2 \mathrm{nmol} / 1$ (reference value in men ranges from 13 to $71 \mathrm{nmol} / \mathrm{l}$ ). Albumin was determined using a colorimetric spectrophotometry kit (Targa BT Plus; Wiener Lab.) with reference values of 3.5-5.5 g/dl. The levels of FSH, LH and prolactin were measured using a chemiluminescence kit (VIDAS; Biolab Merieux). The reference values used in men were: FSH (0.9-15 UI/l), $\mathrm{LH}(1.3-13 \mathrm{UI} / \mathrm{l})$, and prolactin $(<15 \mathrm{ng} / \mathrm{ml})$.

The gold standard for the laboratorial diagnosis of late-onset male hypogonadism was defined as a patient having two values of $\mathrm{cFT}<6.5 \mathrm{ng} / \mathrm{dl}$ obtained according to the Vermeulen formula, with a minimum interval between measurements of one month (3). Using these limits, less than $1 \%$ of healthy men between 20 and 40 years old and more than $20 \%$ of men over 60 years old would have subnormal levels of testosterone (3).

We evaluated the influence of various factors on the values used for diagnosis of the late-onset male hypogonadism such as age, BMI (body mass index - in kg/ $\mathrm{m}^{2}$ ), smoking, depression, hypothyroidism, and use of corticoids, thiazides, and finasteride at the time that the hormonal levels were determined, as well as the time of year that the tests were performed. Bonferroni's Multiple Comparison Test was used to determine whether differences were statistically significant, with a significant level set at $\mathrm{p}<0.05$.

\section{RESULTS}

There were no cases of hyperprolactinemia or abnormal FSH and LH dosages, suggestive of causes of hypogonadism other than andropause in the patients we evaluated.

\section{Factors that influence the hormonal levels}

Age

There was a significant difference $(\mathrm{p}=0.005 \mathrm{l})$ between the average values of TT in patients $<60$ years old ver- 
sus those $\geq 70$ years old $(\mathrm{p}<0.01)$, but, when this comparison was performed among the three age groups $(50-59 ; 60-69 ;>70$ years $)$ there was not a significant difference (Graph 1A).

In the same manner, a significant difference $(\mathrm{p}=$ 0.0003 ) was evident only in the average values of calculated FT obtained for patients $<60$ years old versus those $\geq 70$ years old $(\mathrm{p}<0.001)$ (Graph $1 \mathrm{~B})$.

For the BT, a significant difference $(\mathrm{p}<0.001)$ in the average values was obtained among the three age groups (Graph 1C).

Graph 1. Age influence.

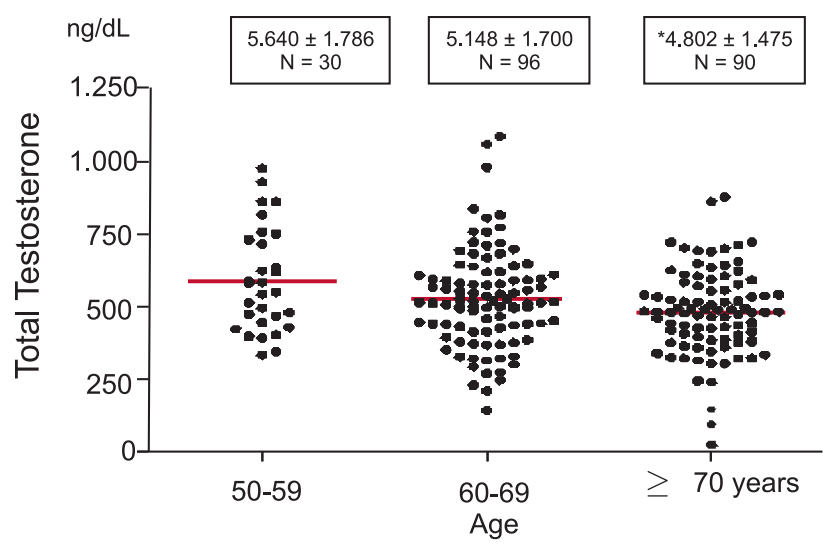

${ }^{*} \mathrm{p}<0.01$ for the total testosterone values obtained when comparing the age groups $<60$ years $v s \geq 70$ years.

Graph 1A. Variation in the TT values by age group.

$\mathrm{ng} / \mathrm{dL}$
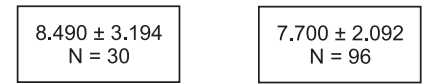

$* 7.330 \pm 2.237$
$N=90$ $\mathrm{N}=90$

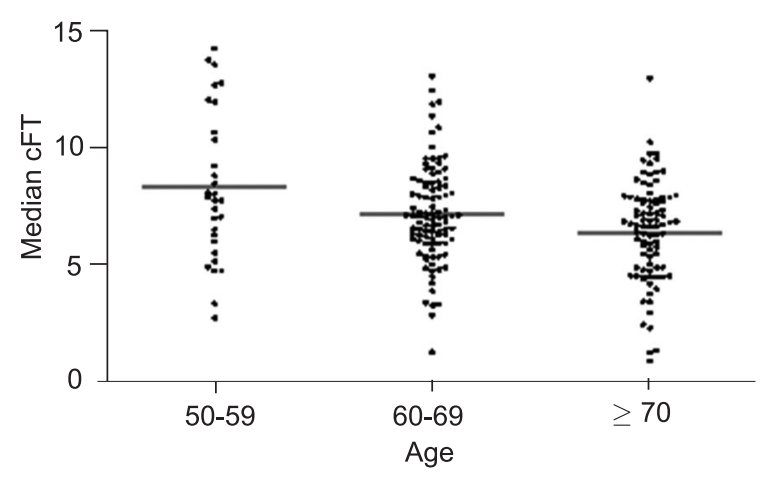

${ }^{*} \mathrm{p}<0.001$ for the values of the calculated free testosterone obtained when comparing the age groups $<60$ years vs $\geq 70$ years.

Graph 1B. Variation in the cFT values by age group. $\begin{aligned} 222.0 & \pm 87.13 \\ N & =30\end{aligned}$

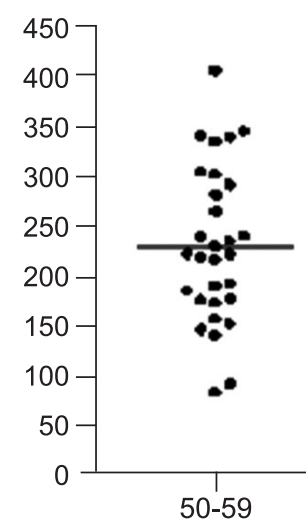

${ }^{*} p<0.05$ for the values of the calculated bioavaiable testosterone
obtained when comparing the age groups $<60$ years vs $60-69$
years; ${ }^{* *} p<0.05$ for the values of the calculated bioavaiable
testosterone obtained when comparing the age groups $60-69$
years vs $\geq 70$ years;
${ }^{* * *} p<0.001$ for the values of the calculated bioavaiable testosterone
obtained when comparing the age groups $<60$ years vs $\geq 70$ years.

Graph 1C. Variation in the cBT values by age group.

There was no significant difference $(\mathrm{p}=0.4234)$ in the average values of SHBG among the evaluated age groups.

\section{Finasteride}

In comparing patients using Finasteride $(\mathrm{n}=3)$ or not, a significant difference was observed for the values of TT $(\mathrm{p}=0.0468)$ and $\mathrm{cFT}(\mathrm{p}=0.0454)$, but not BT $(\mathrm{p}=0.1061)$ or SHBG $(\mathrm{p}=0.8489)$ (Graphs $2 \mathrm{~A}$ and $\mathrm{B})$.

\section{Other analyzed factors}

The other factors that were analyzed (e.g., smoking, time of year when the tests were performed, depression, hypothyroidism, protein consumption, and use of corticoids or thiazides at the time of the testing) did not interfere in a significant way with the hormonal dosages used.

Current smokers $(n=25)$ showed no difference in TT, cFT or BT in relation to non smokers $(n=191$, $\mathrm{p}=0.64 ; 0.12$ and 0.79 respectively). In the same way, no significant difference for these dosages was demonstrated for patients with depression $(\mathrm{n}=7, \mathrm{p}=0.38 ; 0.1$ and 
Graph 2. Influence of the use of Finasteride.

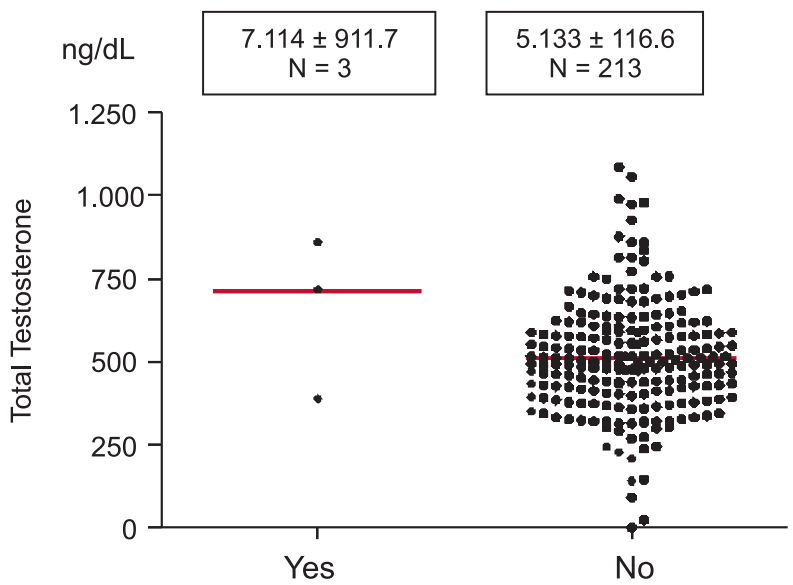

Graph 2A. $\pi$ values of patients using finasteride and those who did not use this medication.

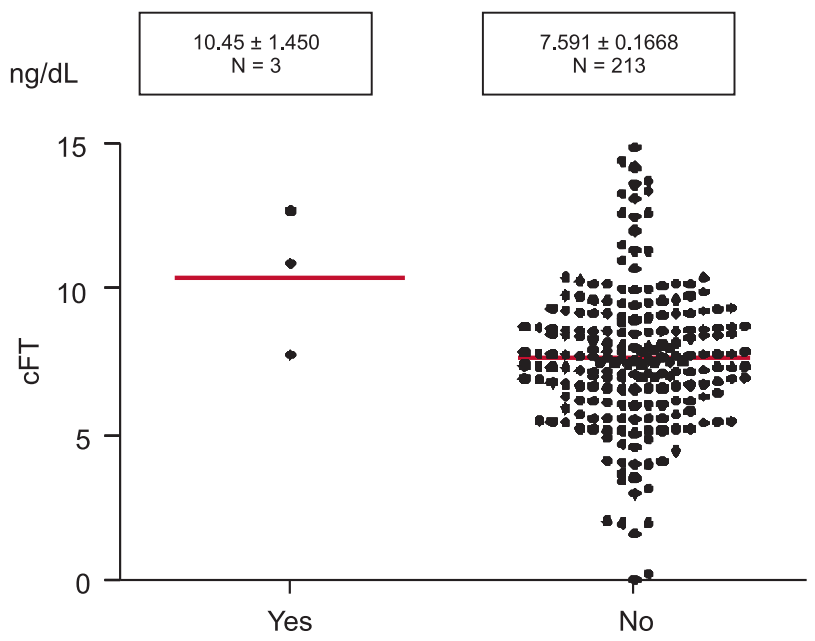

Graph 2B. CFT values of patients using finasteride and those who did not use this medication.

$0.13)$; hypothyroidism $(\mathrm{n}=3, \mathrm{p}=0.74 ; 0.38$ and 0.34$)$; with protein consumption $>100 \mathrm{~g} /$ day $(\mathrm{n}=126, \mathrm{p}=0.81$; 0.56 and 0.29$)$; in use of glucocorticoids $(n=6, p=0.56$; 0.30 and 0.19$)$ or thiazides $(\mathrm{n}=33, \mathrm{p}=0.76 ; 0.78$ and 0.66 , respectively).

The comparison of values obtained from exams performed at the warmer months of the year versus the colder months of the year showed no difference $(\mathrm{p}=0.49$; 0.18 and 0.38 for TT, cFT and BT respectively).

\section{Factors that maske the laboratorial diagnosis of hypogonadism}

At the first blood test, 57 men (27\% of the total sample) showed calculated FT $<6.5 \mathrm{ng} / \mathrm{dl}$. Laboratorial hypogonadism, defined as a patient having two values of calculated FT $<6.5 \mathrm{ng} / \mathrm{dl}$ obtained according to the Vermeulen formula, was diagnosed in 41 men (19\% of the total sample). Therefore almost $30 \%$ of the men with a first $\mathrm{cFT}<6.5 \mathrm{ng} / \mathrm{dl}$ did not confirm this level at a second test.

Only 9 of the men with laboratorial hypogonadism ( $4.2 \%$ of the total sample) had TT below the reference range, while 32 men (14.8\% of the total sample) had normal TT levels, with calculated FT $<6.5 \mathrm{ng} / \mathrm{dl}$ on two occasions.

When we looked at the values of TT at the same dosage where FT was $<6.5 \mathrm{ng} / \mathrm{dl}$, we observed that $17.8 \%$ of the men had TT levels within the reference range and $9.6 \%$ of them even had TT above $400 \mathrm{ng} / \mathrm{dL}$. That was particularly important for men $\geq 70$ years old: $23.5 \%$ of them had normal TT levels and $13.8 \%$ had TT above $400 \mathrm{ng} / \mathrm{dl}$, in spite of cFT being $<6.5 \mathrm{ng} / \mathrm{dl}$.

In relation to the BMI, $38.9 \%$ of the obese patients with TT $>241 \mathrm{ng} / \mathrm{dl}$ showed two measurements of cFT that were $<6.5 \mathrm{ng} / \mathrm{dl}$, as compared to $17.3 \%$ of the patients with BMI between 25 and 30. Even for TT levels $>400 \mathrm{ng} / \mathrm{dl}, 25 \%$ of the patients with BMI $>30$ had demonstrated hypogonadism, while this percentage for those who were overweight was 7.5\% (Tables $1 \mathrm{~A}$ and $\mathrm{B}$ ).

Table 1. Percentage of hypogonadal men with normal total testosterone, according to their BMI.

A. Considering total testosterone $>241 \mathrm{ng} / \mathrm{dL}$.

\begin{tabular}{lccc} 
& $\begin{array}{c}n \text { of men with } \\
\mathbf{\pi} \leq \mathbf{2 4 1} \mathbf{n g} / \mathrm{dl}\end{array}$ & $\begin{array}{c}\mathrm{n} \text { of men with } \\
\mathbf{T}>\mathbf{2 4 1} \mathbf{n g} / \mathrm{dl}\end{array}$ & $\%$ \\
\hline $\mathrm{BMl}>25$ & 18 & 104 & 17.3 \\
\hline $\mathrm{BMl}>30$ & 7 & 18 & 38.9 \\
\hline
\end{tabular}

* Comparing hypogonadal men with $\mathrm{BMl}>25$ and hypogonadal men with $\mathrm{BMI} \leq 25: \mathrm{p}=1.00$; ${ }^{*}$ Comparing hypogonadal men with $\mathrm{BMl}>30$ and hypogonadal men with $B M l \leq 30: p=0.03$.

B. Considering total testosterone $>400 \mathrm{ng} / \mathrm{dL}$.

\begin{tabular}{llllc} 
& $\begin{array}{c}n \text { of men with } \\
\Pi \leq \mathbf{4 0 0} \text { ng/dl }\end{array}$ & $\begin{array}{c}n \text { of men with } \\
\Pi>\mathbf{4 0 0} \mathbf{n g} / \mathrm{dl}\end{array}$ & $\%$ \\
$\mathrm{BMl}>25$ & 6 & 80 & 7.5 \\
$\mathrm{BMl}>30$ & 2 & 8 & 25.0 \\
\hline
\end{tabular}

* Comparing hypogonadal men with $\mathrm{BMl}>25$ and hypogonadal men with BMl $\leq 25: \mathrm{p}=0.00001$; ${ }^{*}$ Comparing Hypogonadal men with $\mathrm{BMl}>30$ and hypogonadal men with $\mathrm{BMl} \leq 30$ : $\mathrm{p}=0.812$. 


\section{DISCUSSION}

We observed a significant influence of age on the dosages of TT and cBT; however, this influence was greater on the cBT. Our analysis correlates well with the literature, which affirms that, for each year after 40 years of age, there is a reduction of $1.2 \%$ of the circulatory levels of $\mathrm{cFT}$ and $1 \%$ of testosterone levels bound to albumin $(5,6)$. The TT levels remain stable up to 50 to 55 years of age; above that, the TT levels also began to lower at a rate of $0.4 \%(6)$ to $0.85 \%$ per year $(7)$. This reduction is approximately $35 \%$ between 25 and 75 years old, meaning that the average TT values for men 75 years of age are approximately $65 \%$ of those found in young men (8). Although the reduction in the TT levels in healthy adult men remains controversial, there is a consensus that the FT and the testosterone bound to albumin, which combined represent the BT, are reduced by $50 \%$ to $60 \%$ between the ages of 25 and 75 years $(8,9)$. Therefore, it is important to emphasize that the TT is not a good marker for the influence of age in the reduction of its serum levels, while $\mathrm{cBT}$ was demonstrated to be more sensitive in showing this reduction. Thus, $\mathrm{cBT}$ is likely to be a better marker for the laboratory diagnosis of hypogonadism. This decrease in male hormones is without doubt related to aging. As demonstrated in the 300 healthy men aged 20 to 100 years old who were studied by Vermeulen (10), subnormal levels of TT and cFT were observed in only $1 \%$ of the population under 40 years old, while this percentage increased to more than $10 \%, 20 \%$, and $40 \%$ in those 40 to 60 years old, 60 to 80 years old, and over 80 years old, respectively. This decline in higher levels of $\mathrm{cFT}$ as compared to TT could be due to the age-dependent increase in the serum concentration of SHBG (10). In our sample, however, we did not find any significant difference in the SHBG in regards to age, as opposed to what has been shown previously (4-7).

Finasteride is an inhibitor of 5 - $\alpha$-reductase, the enzyme that is responsible for the conversion of testosterone to dihydrotestosterone (DHT), and it is used for the treatment of alopecia and prostatic pathologies. By inhibiting DHT synthesis, there is a discrete elevation of LH and testosterone levels (11). However, this treatment reduces the androgenic effects on the tissues that are highly dependent on the local production of DHT, resulting in mild signs and symptoms of hypogonadism (12). The results obtained in our study support those available in the literature on hormonal treatments for prostate cancer and benign prostate hyperplasia. We observed a significant influence of Finasteride on the serum levels of TT and cFT; however, the levels of cBT and SHBG did not have any significant changes. Again, we noted that the dosage of $\mathrm{CBT}$ proved to be more reliable for the laboratory diagnosis of hypogonadism for men using Finasteride, as its levels were not affected by the use of this medication, thus avoiding false negative results for hypogonadism. Despite these results, the number of patients using Finasteride in our sample was very small $(n=3)$, so we are not allowed to conclude that the use of this medication interferes with the laboratorial diagnosis of late onset hypogonadism. The use of Finasteride by athletes in competitions is prohibited by the World Anti-Doping Agency, not because it enhances athletic performance, but because it confounds the evaluation of steroid profiles in sports drug testing. Likewise, Finasteride could mask the laboratorial diagnosis of andropause. Further studies are necessary, with larger numbers of patients using Finasteride, to confirm this finding.

The analysis of other factors, such as smoking, depression, hypothyroidism, the use of corticoids or thiazides at the time of testing, period of the year that the tests were performed (i.e., considering the months between May and August to be "cold" months and the others to be "hot"), and the patient's daily protein consumption, revealed that none of these factors significantly influenced the hormone levels. These results are not totally in agreement with those in the literature; there is some evidence that, in adult men of all ages, the serum levels of TT and cFT are 5\% to $15 \%$ higher in current smokers as compared to non-smokers $(7,13$ 16). Other studies have also demonstrated a positive association between the levels of TT and cFT and smoking (17-21). Besides the suggestion that smoking seems to reduce the risk of hypogonadism, this association has so far not been significant. It was also shown that a reduction in smoking during the follow-up of the patients increased the risk of hypogonadism, at least when this was defined by the levels of TT (7).

The association between depression and changes in the hormonal levels is described in studies, showing a significant inverse relationship between the BDI (Beck Depression Inventory) score, which evaluates the presence of depression and cBT levels, which was independent of age, changes in body weight and physical activity (20). The serum levels of cBT were $17 \%$ lower for the men with depression when compared to the le- 
vels of patients without depression. Other studies $(21,22)$ have shown that hypogonadal patients had significantly higher depression-related scores than those with normal gonadal function; furthermore, with androgenic treatment, there was a significant improvement in these scores. These results suggest that the administration of testosterone may improve depression in elderly men who present low levels of cBT. Further clinical studies are necessary to test this hypothesis.

Thyroid function is known to influence the serum levels of testosterone; thus, hyperthyroidism increases, and hypothyroidism reduces, the levels of SHBG and TT (11).

There exists evidence in the literature that many medications and drugs can cause primary or peripheral adverse effects on testicular function $(11,23)$. Among these drugs, glucocorticoids, stand out (24) inducing the reduction of cFT by combined actions both at the testicular and at the hypothalamic-pituitary level, being these adverse effects in the production of testosterone dose dependent (25-28).

The disagreement between our data and the literature can be related to the small numbers of current smoking patients $(\mathrm{n}=25)$, those who had depression $(n=7)$ or hypothyroidism $(n=3)$, or those who were currently using corticoids $(n=6)$ or thiazides $(n=33)$ in our sample.

Regarding the period of the year the tests were performed, studies have shown that serum levels of TT vary with amplitude levels of greater than $30 \%$, reaching maximum amplitude around October through December in countries in the North hemisphere with greater inter-season thermal variation (29-31). Other studies have shown that there is no significant variation in the maximum levels in summer vs. winter $(30,32)$. A large interindividual difference was also demonstrated, when the study was designed to avoid the influence of the seasonal variations (33). Our weather does not vary greatly as compared to the countries where the previous studies were performed (USA and European countries); for this reason, it should not have significantly influenced the measurement of hormone levels.

Regarding the daily protein consumption, it has been suggested that diets rich in fibers are associated with higher levels of SHBG and TT as compared to Western diets (34-38), without any significant differences in the cFT levels (36). In the Massachusetts Male Aging Study (MMAS), the daily protein and fiber consumption were determinant and independent factors, negative and positive, respectively, of the serum levels of SHBG, while the total caloric, fat or carbohydrate consumption did not significantly contribute. Thus, low-protein diets in elderly men might increase the SHBG levels and, consequently, decrease the biological activity of testosterone (39). In other words, the inverse relationship between the consumption of proteins and the serum levels of SHBG suggest that, in elderly men, a high-protein diet could increase the cBT level and minimize the effects of the reduction of this hormone related to age. Intervention studies are necessary to investigate this hypothesis. We did not observe a significant influence of protein consumption on the hormonal levels, which might be a consequence of the low average daily protein consumption of the evaluated men $(158 \pm 82 \mathrm{~g}$ of food in the meat group/day).

Finally, it is known that the BMI is an important negative determinant of the serum levels of TT, mainly due to its effects on SHBG levels (40). While in young and middle-aged men level I obesity (BMI $\geq 30$ and $\leq$ $35 \mathrm{~kg} / \mathrm{m}^{2}$ ) affects mainly the SHBG and TT levels, obesity levels II and III (BMI $\geq 35 \mathrm{~kg} / \mathrm{m}^{2}$ and BMI $\geq$ $40 \mathrm{~kg} / \mathrm{m}^{2}$, respectively) and the accumulation of visceral fat, in particular, also affect the cFT levels (41-43). We observed in our analysis that, among the patients 70 years of age or older, as well as among those who had a BMI $\geq 30 \mathrm{~kg} / \mathrm{m}^{2}$, a significant number of false negatives could exist in the diagnosis of late-onset male hypogonadism. This would occur if the tests were based only on TT levels because a significant percentage of these patients, even those with normal levels of TT [TT $>241 \mathrm{ng} / \mathrm{dl}$ (lower range of the kit's normal values), TT $>300 \mathrm{ng} / \mathrm{dl}$, or even TT $>400 \mathrm{ng} / \mathrm{dl}$ ], exhibited cFT levels $<6.5 \mathrm{ng} / \mathrm{dl}$ in at least two different tests spaced by at least one month. This is considered the gold standard for the laboratory diagnosis of hypogonadism $(44,45)$. In this manner, the importance of measuring the levels of SHBG and albumin to diagnose hypogonadism in patients 70 years of age or older is clear, as it is also for men of any age with a BMI $\geq 30 \mathrm{~kg} / \mathrm{m}^{2}$; once these conditions can develop with normal levels of TT in the occurrence of low levels of cFT, masking the laboratorial diagnosis of hypogonadism $(44,45)$.

\section{CONCLUSION}

Based on the results of the present work we can conclude that, following the gold standard criteria for laboratorial diagnosis, late-onset hypogonadism was present 
in $19 \%$ of our sample. If we had based our laboratory diagnosis only on TT levels, we would have diagnosed only $4 \%$ of the men and missed almost $15 \%$ of the total sample. If we had based our diagnosis on cFT from only one blood test, we would have overdiagnosed $8 \%$ of the men in the sample.

The TT values in our study varied significantly based on age and BMI. The level of SHBG is especially important in calculating FT in patients 70 years of age or older and also for those patients with $\mathrm{BMI} \geq 30 \mathrm{~kg} /$ $\mathrm{m}^{2}$. A patient in either of these categories will be more likely to have increased levels of SHBG, which can produce normal levels of TT with low levels of cFT, masking the diagnosis of hypogonadism.

Calculated BT proved to be the best marker for the laboratory diagnosis of hypogonadism. It was more sensitive to the influence of age, more specific for the diagnosis, and its levels were not affected by the use of Finasteride.

Further studies are necessary to confirm our findings that Finasteride can mask the laboratorial diagnosis of late-onset hypogonadism.

Acknowledgements: The authors thank the Laboratory Diagnósticos da America and the Instituto Fernandes Figueira, for performing the testing. At the Instituto Fernandes Figueira, special thanks to Jânio Alves Cordeiro (Head of the Department of Clinical Pathology), Marcio Guilherme de Souza (technician responsible for the hormonal analysis) and Rodrigo Batista dos Santos (technician responsible for the blood collection and sampling). In addition, we thank Martha Suárez-Mutis, doctor of epidemiology of IOC-Fiocruz, for the statistical analysis. No potencial conflict of interest relevant to this article was reported.

\section{REFERENCES}

1. Androgen Deficiency Syndromes in Men Guideline Task Force: Bhasin S, Cunningham GR, Hayes FJ, Matsumoto AM, Snyder PJ, Swerdloff RS, Montori VM. Testosterone theraphy in adult men with androgen deficiency syndromes: An Endocrine Society Clinical and Practice Guideline. J Clin Endocrinol Metab. 2006;91:1995-2010.

2. Carnegie C. Diagnosis of hypogonadism: clinical assessments and laboratory tests. Rev Urol. 2004;6 Suppl 6:S3-S8.

3. Rosner W, Auchus RJ, Azziz R, Sluss PM, Raff H. Utility, limitations and pitfalls in measuring testosterone: An Endocrine Society Position Statement. J Clin Endocrinol Metab. 2007;92:405-13.

4. Vermeulen A. Hormonal cut-offs of partial androgen deficiency: a survey of androgens assays. J Endocrinol Invest. 2005;28:28-31.

5. Gooren LJG. The age-related decline of androgen levels in men: clinically significant? Brit J Urol. 1996;78:763-8.
6. Gray A, Feldman A, McKinlay JB, Longcope C. Age, disease, and changing sex hormone levels in middle-aged men: results of the Massachusetts Male Aging Study. J Clin Endocrinol Metab. 1991;73:1016-25.

7. Vermeulen A, Kaufman JM, Giagulli VA. Influence of some biological indices on sex hormone binding globulin and androgen levels in aging and obose males. J Clin Endocrinol Metab 1996; 81:1821-7.

8. Vermeulen A. Andopause. Maturitas. 2000;15:5-15.

9. Vermeulen A. Androgens in the aging male-Clinical review 24 J Clin Endocrinol Metab. 1991;73:221-4.

10. Kaufman JC, Vermeulen A. Androgens in male senescense. In: Nieschlag E, Behre HM, eds. Testosterone. Action, Deficiency, Substitution. Berlin: Springer. 1998; 437-72.

11. Vermeulen A, Giagulli VA, De Schepper P, Buntinx A, Stoner E. Hormonal effects of an orally active 4-azasteroid inhibitor of 5 alpha-reductase in humans. Prostate. 1989;14:45-53.

12. Thompson IM, Goodman PJ, Tangen CM, Lucia MS, Miller GS, Ford LG, et al.. The influence of finasteride on the development of prostate cancer. N Engl J Med. 2003;349:215-24.

13. Deslypere JP, Vermeulen A. Leyding-cell function in normal men - effect of age, life-style, residence, diet and activity. $J$ Clin Endocrinol Metab. 1984;59:955-62.

14. Dai WS, Gutai JP, Kuller LH, Cauley JA. Cigarette-smoking and serum sex-hormones in men. Am J Epidemiol. 1988; 128:796-805.

15. Barret-Connor E, Khaw KT. Cigarette smoking and serum sex hormones in men. Am J Epidemiol. 1987;128:796-805.

16. Field AE, Colditz GA, Willett WC, Longcope C, Mc Kinlay JB. The relation of smoking, age, relative weight, and dietary intake to serum adrenal steroids, sex hormones, and sex hormone-binding globulin in middle-aged men. J Clin Endocrinol Metab. 1994;79:1310-6.

17. Svartberg J, Midtby M, Bonaa KH, Sundsfjord J, Joakimsen $\mathrm{RM}$, Jorde R. The associatios of age, lifestyle factors and chronic disease with testosterone in men: the Tromso Study. Eur J Endocrinol. 2003;149:145-52.

18. Bauman KE, Foshee VA, Koch GG, Haley NJ, Downton MI. Testosterone and cigarette smoking in early adolescence. J Behav Med. 1989;12:425-33.

19. Laaksonen DE, Niskanen L, Punnonen K, Nyyssonen K, Tuomainnen T, Valkonen $\mathrm{V}$, Salonen JT. The metabolic syndrome and smoking in relation to hypogonadism in middle-aged men: a prospective cohort study. J Clin Endocrinol Metab. 2005;90(2):712-9.

20. Barret-Connor E, Von-Muhlen DG, Kritz-Silverstein D. Bioavailable testosterone and depressed mood in older men: the Rancho Bernardo Study. J Clin Endocrinol Metab. 1999; 84(2): 573-77.

21. Burris AS, Banks SM, Carter CS, Davidson JM, Sherins RJ. A long-term, prospective sudy of the physiologic and behavioral effects of hormone replacement in untreated hypogonadal men. J Androl. 1992;13:297-304.

22. Wang C, Alexander G, Berman N, et al. Testosterone replacement therapy improves mood in hypogonadal men - a clinical research center study. J Clin Endocrinol Metab. 1995;81:3578-83.

23. Nagler HM, Olsson CA. Drug-related make sexual dysfunctionIn: Krane RJ, Siroky MB, Goldstein I, eds. Male Sexual Dysfunction. Boston: Little Brown.1983;113-24.

24. MacAdams MR, White RH Chipps BE. Reduction of serum testosterone levels during chronic glucocorticoid therapy. Ann Int Med. 1986;104:648-51. 
25. Reid IR, Ibbertson HK, France JT, Pybus J. Plasma testosterone concentrations in asthmatic men treated with glucocorticoids. Br Med J. 1985;291:574.

26. Kamischke A, Kemper DE, Castel MA, Luthke M, Rolf C, Behre $\mathrm{HM}$, Magnussen $\mathrm{H}$, Nieschlang E. Testosterone levels in men with chronic obstructive pulmonary disease with or without glucocorticoid therapy. Eur Respir J. 1998;11:41-5.

27. Doerr P, Pirke KM. Cortisol-induced suppressionof plasma testosterone in normal adult males. J Clin Endocrinol Metab. 1976; 43:622-9.

28. MacAdams MR, White RH, Chipps BE. Reduction of serum testosterone levels during chronic glucocrticoid therapy. Ann Interm Med. 1986;104:648-51.

29. Smals AGH, Kloppenborg PWC, Benraad TJ. Circannual cycle in plasma testosterone levels in man. J Clin Endocrinol Metab. 1976;42:979-82.

30. Svartberg J, Jorde R, Sundsfjord J, Bonaa KH, Barrett-Connor E. Seasonal variation of testosterone and waist to hip ratio in men: the Tromso Study. J Clin Endocrinol Metab. 2003;88:3099-104.

31. Dabbs JM, Jr. Age and seasonal variation in serum testosterone concentration among men. Chronobiol Int 1990; 7:245-249.

32. Brambilla DJ, O'Donnel AB, Matsumoto AM, McKinlay JB. Lack of seasonal variation in serum sex hormone levels in middle-aged to older men in the Boston area. J Clin Endocrinol Metab [in press].

33. Kaufman JC, Vermeulen A. Androgens in male senescense. In: Nieschlag E, Behre HM, eds. Testosterone. Action, Deficiency, Substitution. 3. ed, Cambridge University Press; 2004. p. 497-541.

34. Reed MJ, Cheng RW, Simmonds M, Richmond W, James VHT. Dietary lipids - an additional regulator of plasma-levels of sexhormone binding globulin. J Clin Endocrinol Metab. 1987;64: 1083-85.

35. Belanger A, Locong A, Noel C, Cusan L, Dupont A, Presvot J, et al. Influence of diet on plasma steroid and sex plasma-binding globulin levels in adult men. J Steroid Biochem Molec Biol. 1989;32:829-33.

36. Key TJA, Roe L, Thorogood M, Moore JW, Clarck GMG, Wang DY. Testosterone, sex hormone-binding globulin, calculated calculated free testosterone, and estradiol in male vegans and omnivores. Brit J Nutr. 1990;64:111-9.

37. Adlercreutz H. Western diet and western diseases - some hormonal and biochemical-mechanisms and associations. Scandinavian J Clin Lab Invest. 1990;50:3-23.

38. Hamalainen EK, Adlercreutz H, Puska P, Pietinen P. Decrease of serum total and calculated free testosterone during a low-fat high-fiber diet. J Steroid Biochem Molec Biol. 1983;18:369-70.

39. Kaufman JM, Vermeulen A. The decline of androgen levels in eldery men and its clinical and therapeutic implications. Endocrine Reviews. 2005.

40. Demoor P, Goossnens JV. An inverse correlation between body weight and the activity of the steroid binding globulin in human plasma. Steroidologia. 1970;1:129-36.

41. Giagulli VA, Kaufman JM, Vermeulen A. Pathogenesis of the decreased androgen levels in obese men. J Clin Endocrinol Metab. 1994;79:997-1000.

42. Haffner SM, Valdez RA, Stern MP, Katz MS. Obesity, body-fat distribution and sex-hormones in men. Int J Obesity. 1993; 17: 643-9.

43. Zumoff B, Strain GW, Miller LK, Rosner W, Senie R, Seres DS, Rosenfeld RS. Plasma-free and non-sex-hormone-bindingglobulin-bound testosterones are decreased in obese men in proportion to their degree of obesity. J Clin Endocrinol Metab. 1990;71:929-31.

44. Morales A, Lunenfeld B. Investigation, treatment and monitoring of late-onset hypogonadism in males. Official Recommendations of ISSAM. The Aging Male. 2002;5:74-86.

45. Nieschlang E, Swerdloff R, Behre HM, Gooren LJ, Kaufman JM, Legros JJ, et al. Investigation, treatment and monitoring of late-onset hypogonadism in males. ISA, ISSAM and EAU Recomendations. Eur Urol. 2005;48:1-4.

\section{Correspondence to:}

Aline Machado do Carmo

Rua Constante Sodré, 1195/801, Praia do Canto

29055-420 Vitória ES

E-mail: alinemcarmo@terra.com.br 